\title{
Article \\ Research into Cryolithozone Spatial Pattern Changes Based on the Mathematical Morphology of Landscapes
}

\author{
Alexey Victorov*(D), Veronika Kapralova (D), Timofey Orlov, Olga Trapeznikova and Maria Arkhipova \\ IEG RAS, Ulanskii pereulok 13, 101000 Moscow, Russia; vkapralova@gmail.com (V.K.); \\ tim.orlov@gmail.com (T.O.); ontolga@gmail.com (O.T.); masha-a@yandex.ru (M.A.) \\ * Correspondence: vic_as@mail.ru
}

Citation: Victorov, A.; Kapralova, V.; Orlov, T.; Trapeznikova, O.;

Arkhipova, M. Research into

Cryolithozone Spatial Pattern

Changes Based on the Mathematical Morphology of Landscapes. Energies 2022, 15, 1218. https://doi.org/

$10.3390 /$ en15031218

Academic Editors: Gleb Kraev, Sergey Kudryavtsev, Alexey Maslakov, Ogla Makarieva and Jacek Majorowicz

Received: 7 December 2021

Accepted: 2 February 2022

Published: 7 February 2022

Publisher's Note: MDPI stays neutral with regard to jurisdictional claims in published maps and institutional affiliations.

Copyright: (C) 2022 by the authors. Licensee MDPI, Basel, Switzerland. This article is an open access article distributed under the terms and conditions of the Creative Commons Attribution (CC BY) license (https:// creativecommons.org/licenses/by/ $4.0 /)$.

\begin{abstract}
Lacustrine thermokarst is receiving great interest as a landscape-forming process. Despite this, research dealing with the quantitative analysis of the changes in the morphological patterns of thermokarst plains under ongoing climate change is lacking. This study aims to analyze changes in the morphological patterns of cryolithozone landscapes based on models provided by the mathematical morphology of landscapes. Our research involves eight key sites within lacustrine thermokarst plains and nine key sites within thermokarst plains with fluvial erosion. These sites differ in geomorphological, geocryological, and physiographical terms, and are situated in different regions such as Yamal, Taimyr, Kolyma lowland, river Lena delta, Baffin's Land, and Alaska. Archival Corona images (date 1) and high-resolution satellite imagery from June to August 2008-2014 (date 2) were used to obtain the model's morphometric data. According to quantitative analysis of the models, the morphological pattern of the lacustrine thermokarst plains did not undergo significant changes during the observation period, while $20 \%$ of the key sites within the thermokarst plains with fluvial erosion underwent essential changes in lake area distributions. This difference may come from the higher reactivity of the fluvial erosion process on climate change than that of the thermokarst.
\end{abstract}

Keywords: mathematical morphology of landscapes; lacustrine thermokarst plains; thermokarst plains with fluvial erosion; integral-exponential distribution; random process theory; space imagery

\section{Introduction}

The Arctic Cryolithozone is characterized by a significant predominance of lowlands and low-lying outskirts of plains. There is a lot of lacustrine thermokarst in these areas. At the same time, major oil and gas fields are located there. These territories are being actively developed, including via exploration, production, transportation of petroleum products, and construction of engineering structures.

There are several main modern trends in studying changes in landscapes in the permafrost zone.

Firstly, there is the analysis of cryolithozone landscape changes, including global generalizations ([1], for example). Some works deal with ground-condition changes. For one, Ref. [2] showed that $25 \%$ of the East-Siberian submeridional transect would experience permafrost degradation until 2009, Ref. [3] except Alaska, which would lose up to $22 \%$ of its permafrost soil. Another set of studies observes temperature changes, such as [4]. These demonstrate contrasting trends of permafrost temperatures with prevailing warming at $1.2{ }^{\circ} \mathrm{C}$. Ref. [5], and also matched contrasting permafrost temperature trends by analyzing bores in the Chara depression during 1986-2020. Many researchers have studied climatic changes and consequent processes in the cryolithozone ([6] and many others). Some of them are devoted to changes concerning exogenous processes in the cryolithozone [7], and some works deal with vegetation-soil cover changes [8]. The authors in [9] revealed that wood fires are an important factor for permafrost degradation, along with air temperature, but wood fires are almost absent in the tundra zone. They also found that permafrost 
degrades very intensively but within relatively small patches; the authors in [10] comes to a similar conclusion.

Many pieces of research deal with lacustrine thermokarst as one of the landscapeforming processes. For this, we can point to works that focus on assessing the spatial position of lacustrine thermokarst in Alaska [11] and Eastern Siberia, which are very important [12]. The authors in [13] showed that thermokarst lakes have expanded over the last 8000 years. Furthermore, 5000 years ago, the distribution of thermokarst lakes was about the same as today. Until 2000 years ago, the levels of thermokarst lakes were higher than modern ones, and then the lakes began to decrease. For the territory of Alaska, Ref. [14] found that the studied lakes appeared about 11,000-12,000 years ago, as is typical with thermokarst lakes. The coastlines of these lakes have been practically stable for the past 9000 years, up to now. The authors in [15] found that the area of thermokarst lakes in northwestern Alaska is decreasing, and is associated with the intensification of thermal erosion due to an increase in the average annual temperature. At the same time, the average annual precipitation has remained practically unchanged since 1984. The research in [16] established the growth of thermokarst lakes as 4.5\% from 1999 to 2018 in the Kolyma lowland. Furthermore, Ref. [17] showed that the development of thermocirques is the main factor affecting the concentration of organic matter in the lakes, which provide its lateral inflow. The authors in [18] found that the total lake area within Yukon plains decreased, with the main decrease occurring in the 1970s and 1990s, but their number, on the contrary, has increased. The catastrophic descent of the lakes has been responsible for half of the lake area reduction. The descents of lakes occurred more frequently in the past few decades due to the activation of the thermokarst process under climate warming. At the same time, Ref. [19] showed that the number of thermokarst lakes in the study area increased by $10 \%$ over 60 years, while the total lake area decreased. The reason for this is the formation of rudimentary lakes after the descent of large thermokarst lakes. On the contrary, the number of large lakes has decreased. At the same time, the dried lakes have been expanding because of permafrost melting. The authors in [20] found that $12 \%$ of landscapes near Eight Mile Lake (Canada) are characterized by the emergence of new, initial thermokarst forms. The study in [21] revealed a multidirectional trend in the lake size changes from remote sensing data: a 14\% increase by 1994 and a 10\% decrease in 1999-2002, compared with 1984.

Lacustrine thermokarst forms a special spatial pattern on a landscape surface, which can be studied both in itself and as an indicator of ongoing processes.

However, only a few works have examined changes in the morphological patterns of cryolithozone landscapes. As a rule, these works only examine the change in the lake share within landscapes, the number, and area of the lakes, and sometimes their dynamics [22-25]. The authors in [26] tried to find a distribution function for lake areas, without much success. Furthermore, Ref. [27] estimated spatial parameters of lakes in the Lena Delta. Modern techniques for space imagery processing allow us to involve large areas, to which many studies are devoted [25,28,29].

Mathematical modeling is a promising way to study such images (morphological patterns). Traditionally, such modeling of the development and changes in the spatial pattern is widely used to study fluvial erosion. For example, Ref. [30] used the landscape evolution model and dimensional analysis to study the similarity of the erosion network at different scales and in different landscapes. Furthermore, Ref. [31] use fractal dimensions and flow order to compare erosion networks of different origins (rivers, glaciers, underground rivers, etc.). The authors in [32] showed the possibility of modeling evenly spaced ridges and valley patterning processes. As for erosion patterns, modeling is used by many researchers.

However, at the same time, the modeling of the formation processes of plains with a wide development of thermokarst processes is insufficiently developed. The quantitative regularities of changes in their pattern are poorly studied. Researchers rarely propose models that describe the behavior of the quantitative characteristics of morphological patterns. 
The aim of this research is the quantitative analysis of changes in the morphological patterns of cryolithozone landscapes based on the approach of the mathematical morphology of landscapes, which involves two widespread cryolithozone landscapes:

- Lacustrine thermokarst plains;

- (Lacustrine) thermokarst plains with fluvial erosion.

\section{Materials and Methods}

Research Area. This research involves eight key sites within the landscapes of lacustrine thermokarst plains and nine key sites within thermokarst plains with fluvial erosion, all in the circumarctic region.

Lacustrine thermokarst plains represent an undulating, subhorizontal surface, dominated by different tundra or forest-tundra vegetation and embedded thermokarst lakes. The lakes have an isometric and often round shape, and are randomly scattered on the plains (Figure 1). Sometimes, due to confluence, there are lakes with scalloped shapes.

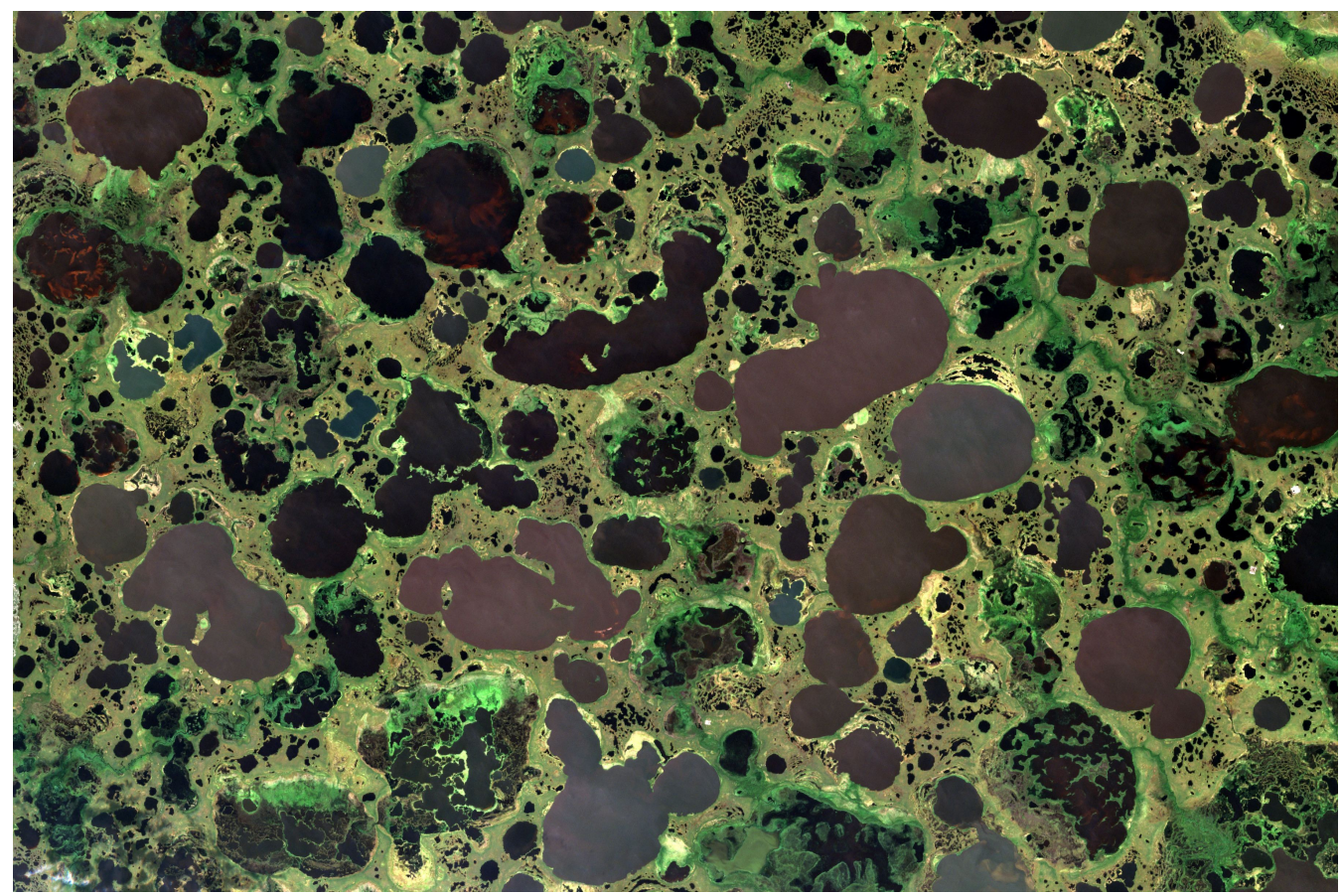

Figure 1. Typical space image of a lacustrine thermokarst plain.

We chose eight key sites for our research, differing in geomorphological, geocryological, and physiographical terms, all situated in different regions such as Yamal, Taimyr, Kolyma lowland, river Lena delta, and Alaska (Figure 2). The description of the key sites is presented in Table 1. 


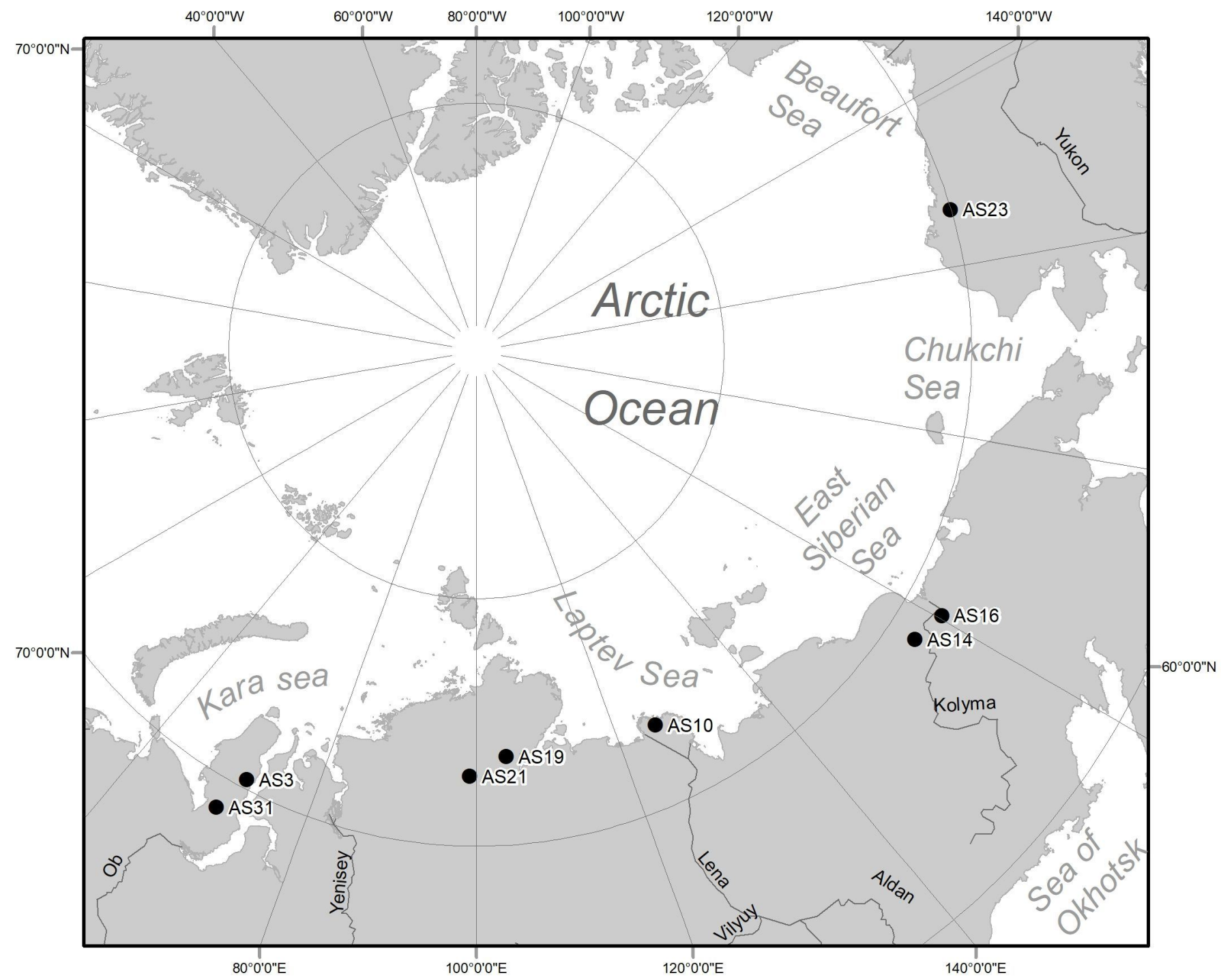

Figure 2. An overview map of key sites for the study of lacustrine thermokarst plains.

Table 1. Natural characteristics of the key sites within the lacustrine thermokarst plains.

\begin{tabular}{|c|c|c|c|c|}
\hline $\begin{array}{l}\text { Key Site (and Its } \\
\text { Area } \mathbf{k m}^{2} \text { ) }\end{array}$ & Region & $\begin{array}{c}\text { Annual Rock } \\
\text { Temperature }{ }^{\circ} \mathrm{C}\end{array}$ & $\begin{array}{c}\text { Permafrost } \\
\text { Thickness (m) }\end{array}$ & Description \\
\hline $\begin{array}{c}\text { AS31 } \\
(78)\end{array}$ & $\begin{array}{c}\text { Yamal peninsula, } \\
\text { Baydaratsko- } \\
\text { Yuribeysky } \\
\text { region }\end{array}$ & -5 & $150-250$ & $\begin{array}{c}\text { The flat and swampy third marine terrace, composed of sandy, sandy loam } \\
\text { and loamy deposits. The rocks are medium-icy (0.2-0.4). Continuous } \\
\text { permafrost. Ref. [33] Vegetation: southern hypoarctic tundra-shrub and } \\
\text { tussock tundra (Betula nana, Salix lapponum, S. phylicifolia, S. dasyclados, } \\
\text { S. glauca, S. lanata, Empetrum hermaph-roditum; Vaccinium myrtillus, } \\
\text { V. uliginosum ssp. microphyllum, V. vitis-idaea ssp. minus и s. str., Deschampsia } \\
\text { flexuosa, Festuca ovina, Aconitum septen-trionale, Cirsium helenioides, } \\
\text { Trolius europaeus, T. asiaticus) [34]. }\end{array}$ \\
\hline $\begin{array}{l}\text { AS3 } \\
(58)\end{array}$ & $\begin{array}{l}\text { East Yamal, } \\
\text { Mudriyakha }\end{array}$ & -7 & $200-280$ & $\begin{array}{l}\text { The densely dissected first and second lagoon-marine terraces, composed of } \\
\text { fine and silty sands, with frequent replacement by sandy loams and rare } \\
\text { interlayers of loams with occasional lenses of gravel and pebbles. The rocks } \\
\text { are highly icy ( }>0.4 \text { ). Continuous permafrost. Ref. [33] Vegetation: northern } \\
\text { hypoarctic (typical) tundra (Cassiope tetragona, Empetrum subholarcticum, } \\
\text { Arctous alpina, Dryas octopetala, Vaccinium uliginosum ssp. microphyllum, } \\
\text { V. vitisidaea ssp. minus, Ledum decumbens, Eriophorum angustifolium, } \\
\text { Carex arctisibirica, Arctagrostis latifolia, Dupontia fisheri, D. psilosantha, } \\
\text { Deschampsia borealis, D. brevifolia, Betula nana, Salix arctica, S. glauca, } \\
\text { S. lanata) [34]. }\end{array}$ \\
\hline
\end{tabular}


Table 1. Cont.

\begin{tabular}{|c|c|c|c|c|}
\hline $\begin{array}{c}\text { Key Site (and Its } \\
\text { Area } \mathbf{k m}^{2} \text { ) }\end{array}$ & Region & $\begin{array}{c}\text { Annual Rock } \\
\text { Temperature }{ }^{\circ} \mathrm{C}\end{array}$ & $\begin{array}{l}\text { Permafrost } \\
\text { Thickness (m) }\end{array}$ & Description \\
\hline $\begin{array}{l}\text { AS21 } \\
(343)\end{array}$ & Central Taimyr & -9 & 900-1100 & $\begin{array}{l}\text { Hilly-ridged Upper Quaternary fluvioglacial plain, composed of boulder } \\
\text { loams, boulders, blocks with loamy rubble, layered sands and pebbles. } \\
\text { Continuous permafrost. Ref. [33] Vegetation: southern hypoarctic } \\
\text { tundra-shrub and tussock tundra (Betula nana, Salix lapponum, } \\
\text { S. phylicifolia, S. dasyclados, S. glauca, S. lanata, Empetrum hermaphroditum; } \\
\text { Vaccinium myrtillus, V. uliginosum ssp. microphyllum, V. vitisidaea ssp. minus и } \\
\text { s. str., Deschampsia flexuosa, Festuca ovina, Aconitum septentrionale, } \\
\text { Cirsium helenioides, Trolius europaeus, T. asiaticus) [34]. }\end{array}$ \\
\hline $\begin{array}{l}\text { AS19 } \\
(303)\end{array}$ & Central Taimyr & -8 & $900-1100$ & $\begin{array}{c}\text { Hilly-ridged Upper Quaternary fluvioglacial plain, composed of boulder } \\
\text { loams, boulders, blocks with loamy rubble, layered sands and pebbles. } \\
\text { Continuous permafrost. Ref. [33] Vegetation: southern hypoarctic } \\
\text { tundra-shrub and tussock tundra (Betula nana, Salix lapponum, S. phylicifolia, } \\
\text { S. dasyclados, S. glauca, S. lanata, Empetrum hermaphroditum; Vaccinium } \\
\text { myrtillus, V. uliginosum ssp. microphyllum, V. vitisidaea ssp. minus и s. str., } \\
\text { Deschampsia flexuosa, Festuca ovina, Aconitum septentrionale, Cirsium helenioides, } \\
\text { Trolius europaeus, T. asiaticus) [34]. }\end{array}$ \\
\hline $\begin{array}{l}\text { AS10 } \\
(378)\end{array}$ & $\begin{array}{l}\text { Delta of the } \\
\text { Lena River }\end{array}$ & $-11-13$ & $400-600$ & $\begin{array}{l}\text { The second sandy Middle-Late Quaternary terrace of the deltaic plain, } \\
\text { composed of sands and specific organogenic sediments. Highly icy rocks. } \\
\text { Ref. [33] Vegetation: arctic tundra (Salix polaris, S. reptans, Dryas punctata, } \\
\text { D. octopetala, Cassiope tetragona; Saxifraga hieracifolia, S. hirculus, S. serpyllifolia } \\
\text { ssp. glutinosa, Alopecurus alpinus, Deschampsia borealis, D. brevifolia, Dupontia } \\
\text { fisheri, Luzula confusa, L. nivalis, Eriophorum angustifolium, E. scheuchzeri, } \\
\text { Carex arctisibirica) [34]. }\end{array}$ \\
\hline $\begin{array}{l}\text { AS14 } \\
(185)\end{array}$ & Kolyma lowland & $-6.7-9$ & $400-500$ & $\begin{array}{l}\text { Lacustrine-alluvial Pleistocene accumulative plain, composed mainly of } \\
\text { horizontally layered silts interbedded with sands and peat. Continuous } \\
\text { permafrost. Ref. [33] Vegetation: pre-tundra light forests with southern } \\
\text { hypoarctic tundras and swamps (Larix gmelinii, L. Cajanderi, Salix udensis, } \\
\text { S. schwerin, Chosenia arbutifolia, Populus suaveolens) [34]. }\end{array}$ \\
\hline $\begin{array}{l}\text { AS16 } \\
(318)\end{array}$ & $\begin{array}{l}\text { Right bank of the } \\
\text { lower Kolyma }\end{array}$ & $-7.8-10$ & $400-500$ & $\begin{array}{l}\text { Heavily peaty lacustrine-alluvial Pleistocene-Holocene plain, composed of } \\
\text { loams, sandy loams, with a high content of silts. Continuous permafrost. } \\
\text { Ref. [33] Vegetation: pre-tundra light forests with southern hypoarctic } \\
\text { tundras and swamps (Larix gmelinii, L. Cajanderi, Salix udensis, S. schwerin, } \\
\text { Chosenia arbutifolia, Populus suaveolens) [34]. }\end{array}$ \\
\hline $\begin{array}{l}\text { AS23 } \\
(333)\end{array}$ & Alaska & -8 & $200-300$ & $\begin{array}{l}\text { Structural-accumulative plain, composed of eolian sands. Ice content is less } \\
\text { than } 0.1 \text {. Continuous permafrost.The dominant vegetation is a wet sedge } \\
\text { meadow of Eriophorum angustifolium and Carex aquafilis. Eriophorum } \\
\text { vaginatum, while tussock tundra occurs on the dryer sites [35]. }\end{array}$ \\
\hline
\end{tabular}

The thermokarst plains with fluvial erosion are slightly wavy, subhorizontal or hilly, deserted areas covered by tundra and forest-tundra vegetation, interspersed with lakes and khasyreis (drained lakes). The lakes have isometric, often roundish shapes, while the khasyreis are former lake depressions containing meadow or bog vegetation and residual, not fully drained lakes. The khasyreis are also of a roundish shape. Both of them are randomly distributed across the plain (Figure 3). Sometimes, because of confluence, there are lakes with scalloped shapes.

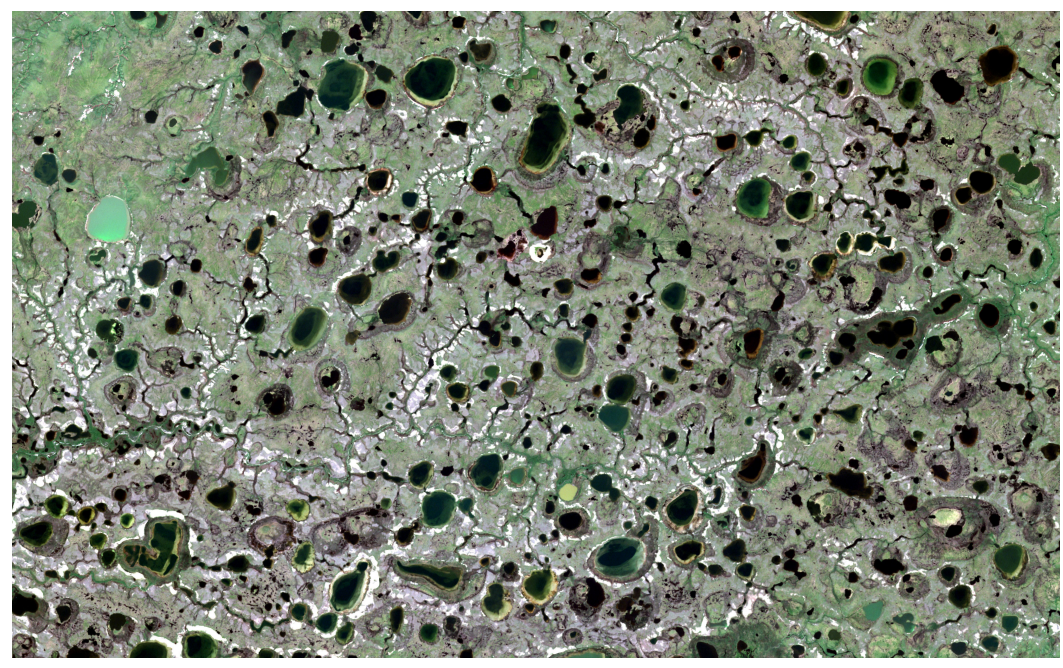

Figure 3. Typical space image of a thermokarst plain with fluvial erosion. 
We chose nine key sites for our research, differing in geomorphological, geocryological, and physiographical terms and situated in different regions. They are located north of the West Siberian Lowland, at the mouth of the river Lena, in Baffin's Land, Eastern Siberia (Figure 4). The description of the key sites is presented in Table 2.

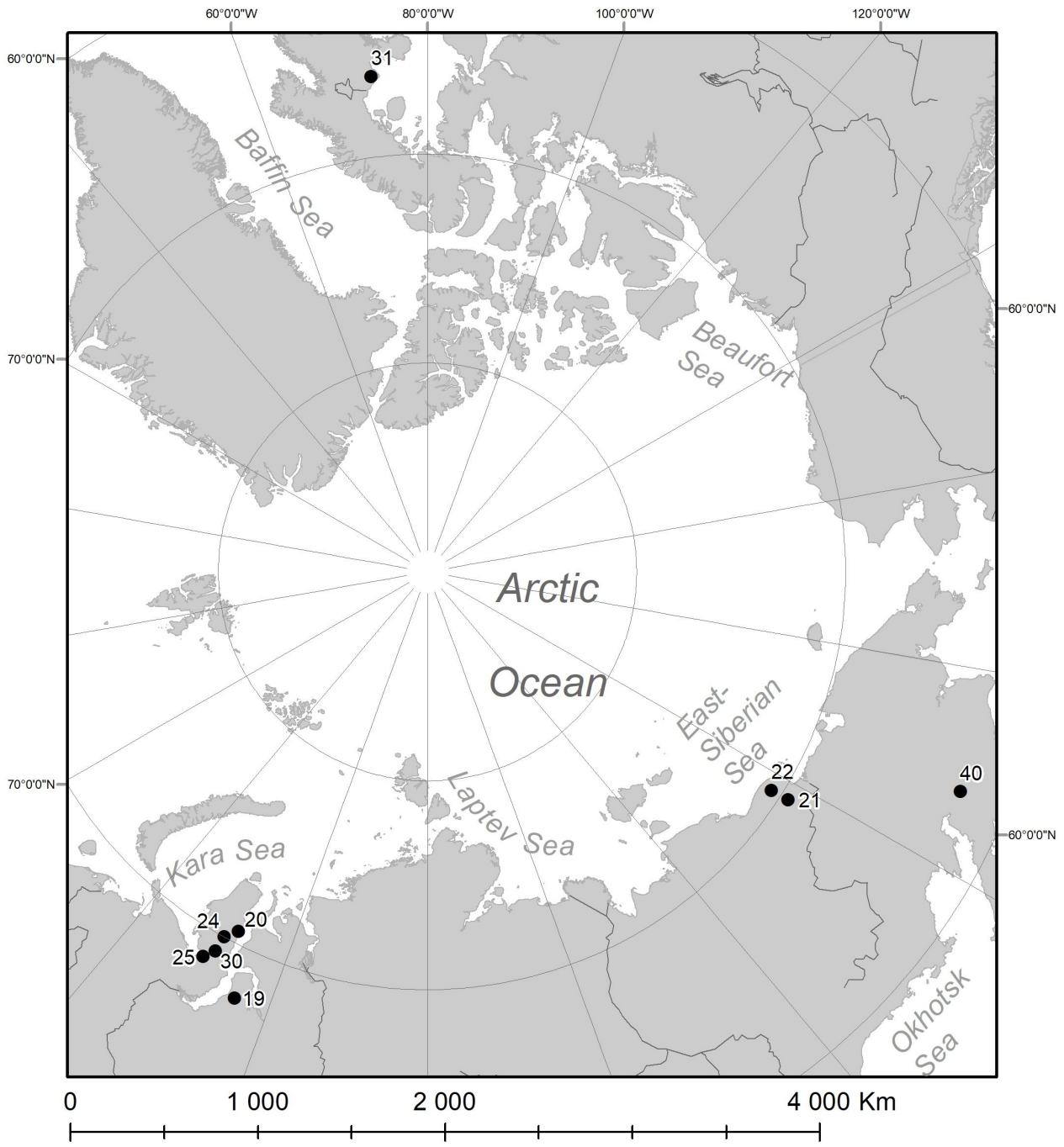

Figure 4. An overview map of key sites for the study of thermokarst plains with fluvial erosion.

Table 2. Natural characteristics of the key sites within the thermokarst plains with fluvial erosion.

\begin{tabular}{|c|c|c|c|c|}
\hline $\begin{array}{c}\text { Key site (and Its } \\
\text { Area } \mathbf{k m}^{2} \text { ) }\end{array}$ & Region & $\begin{array}{c}\text { Annual Rock } \\
\text { Temperature }{ }^{\circ} \mathrm{C}\end{array}$ & $\begin{array}{l}\text { Permafrost } \\
\text { Thickness (m) }\end{array}$ & Description \\
\hline $\begin{array}{c}19 \\
(207)\end{array}$ & Taz Peninsula & $-3--5$ & $200-300$ & $\begin{array}{c}\text { The third and fourth alluvial-marine terraces, composed of sandy loams, } \\
\text { partly replaced by loams. Continuous permafrost. Ref. [33] Vegetation: } \\
\text { southern hypoarctic tundra-shrub and tussock tundra (Betula nana, Salix } \\
\text { lapponum, S. phylicifolia, S. dasyclados, S. glauca, S. lanata, Empetrum } \\
\text { hermaphroditum; Vaccinium myrtillus, V. uliginosum ssp. microphyllum, , minus } \\
\text { u s. str., Deschampsia flexuosa, Festuca ovina, Aconitum septentrionale, } \\
\text { Cirsium helenioides, Trolius europaeus, T. asiaticus) [34]. }\end{array}$ \\
\hline $\begin{array}{c}20 \\
(450)\end{array}$ & Yamal Peninsula & $-7--9$ & $200-300$ & $\begin{array}{l}\text { The first alluvial-marine terrace of the Gulf of Ob, composed of fine and } \\
\text { fine-grained sands; there are lenses of peat and interlayers of sandy loams, } \\
\text { less often loans. Continuous permafrost. Ref. [33] Vegetation: northern } \\
\text { hypoarctic (typical) tundra (Cassiope tetragona, Empetrum subholarcticum, } \\
\text { Arctous alpina, Dryas octopetala, Vaccinium uliginosum ssp. microphyllum, } \\
\text { V. vitis-idaea ssp. minus, Ledum decumbens, Eriophorum angustifolium, Carex } \\
\text { arctisibirica, Arctagrostis latifolia, Dupontia fisheri, D. psilosantha, Deschampsia } \\
\text { borealis, D. brevifolia, Betula nana, Salix arctica, S. glauca, S. lanata) [34]. }\end{array}$ \\
\hline
\end{tabular}


Table 2. Cont.

\begin{tabular}{|c|c|c|c|c|}
\hline $\begin{array}{l}\text { Key site (and Its } \\
\text { Area } \mathbf{k m}^{2} \text { ) }\end{array}$ & Region & $\begin{array}{c}\text { Annual Rock } \\
\text { Temperature }{ }^{\circ} \mathrm{C}\end{array}$ & $\begin{array}{c}\text { Permafrost } \\
\text { Thickness (m) }\end{array}$ & Description \\
\hline $\begin{array}{c}21 \\
(1157)\end{array}$ & $\begin{array}{c}\text { Indigirka-Kolyma } \\
\text { interfluve }\end{array}$ & $-7--9$ & $200-400$ & $\begin{array}{l}\text { A lacustrine-marsh plain composed of lacustrine icy sandy loams with } \\
\text { interbeds of clayey silts, often compacted by lenses and interbeds of peat, } \\
\text { less often by clayey sands with massive cryotextures and large ice veins. } \\
\text { Continuous permafrost. Ref. [33] Vegetation: southern hypoarctic tundra } \\
\text { (Betula exilis, Salix alaxensis, S. boganidensis, S. pulchra, S. glauca, S. reptans, } \\
\text { S. richardsonii, Alnus fruticosa, Eriophorum vaginatum, Ledum decumbens, } \\
\text { Vaccinium vitis-idaea ssp. minus) [34]. }\end{array}$ \\
\hline $\begin{array}{c}22 \\
(2867)\end{array}$ & $\begin{array}{c}\text { Indigirka-Kolyma } \\
\text { interfluve }\end{array}$ & $-9--11$ & $400-500$ & $\begin{array}{l}\text { A lacustrine-marsh plain composed of lacustrine icy sandy loams with } \\
\text { interbeds of clayey silts, often compacted by lenses and interbeds of peat, } \\
\text { less often by clayey sands with massive cryotextures and large ice veins. } \\
\text { Continuous permafrost. Ref. [33] Vegetation: northern hypoarctic (typical) } \\
\text { tundra-(Salix fuscescens, Arctous alpina, Dryas punctata, Vaccinium uliginosum } \\
\text { ssp. microphyllum, V. vitis-idaea ssp. minus, Ledum decumbens, } \\
\text { Empetrum subholarcticum, Eriophorum vaginatum, E. angustifolium, } \\
\text { Carex arctisibirica, Arctagrostis latifolia, Dupontia psilosantha, D. fisheri, } \\
\text { Deschampsia borealis, D. Brevifolia, Betula exilis, Salix richardsonii, S. glauca, } \\
\text { S. pulchra) [34]. }\end{array}$ \\
\hline $\begin{array}{c}24 \\
(154)\end{array}$ & Yamal Peninsula & $-7--9$ & $200-300$ & $\begin{array}{l}\text { The second alluvial-marine terrace of the Gulf of Ob, composed of sands } \\
\text { with thin interlayers of sandy loams and loams up to } 10 \mathrm{~m} \text { thick. Continuous } \\
\text { permafrost. Ref. [33] Vegetation: northern hypoarctic (typical) tundra } \\
\text { (Cassiope tetragona, Empetrum subholarcticum, Arctous alpina, Dryas octopetala, } \\
\text { Vaccinium uliginosum ssp. microphyllum, V. vitisidaea ssp. minus, } \\
\text { Ledum decumbens, Eriophorum angustifolium, Carex arctisibirica, } \\
\text { Arctagrostis latifolia, Dupontia fisheri, D.psilosantha, Deschampsia borealis, } \\
\text { D. brevifolia, Betula nana, Salix arctica, S. glauca, S. lanata) [34]. }\end{array}$ \\
\hline $\begin{array}{c}25 \\
(202)\end{array}$ & Yamal Peninsula & $-5--7$ & $200-300$ & $\begin{array}{l}\text { The first and second marine terraces, composed of several units of sandy, } \\
\text { sandy-argillaceous sediments with lenses and interlayers of sandy loam and } \\
\text { clay. Continuous permafrost. Ref. [33] Vegetation: southern hypoarctic } \\
\text { tundra-shrub and tussock tundra (Betula nana, Salix lapponum, S. phylicifolia, } \\
\text { S. dasyclados, S. glauca, S. lanata, Empetrum hermaphroditum; } \\
\text { Vaccinium myrtillus, V. uliginosum ssp. microphyllum, V. vitisidaea ssp. minus и } \\
\text { s. str., Deschampsia flexuosa, Festuca ovina, Aconitum septentrionale, } \\
\text { Cirsium helenioides, Trolius europaeus, T. asiaticus) [34]. }\end{array}$ \\
\hline $\begin{array}{c}30 \\
(441)\end{array}$ & Yamal Peninsula & $-7--9$ & $300-400$ & $\begin{array}{l}\text { The fourth marine terrace, composed of sandy, sandy loamy and loamy } \\
\text { deposits. Continuous permafrost. Ref. [33] Vegetation: southern hypoarctic } \\
\text { tundra-shrub and tussock tundra (Betula nana, Salix lapponum, S. phylicifolia, } \\
\text { S. dasyclados, S. glauca, S. lanata, Empetrum hermaphroditum; } \\
\text { Vaccinium myrtillus, V. uliginosum ssp. microphyllum, V. vitisidaea ssp. minus и } \\
\text { s. str., Deschampsia flexuosa, Festuca ovina, Aconitum septentrionale, } \\
\text { Cirsium helenioides, Trolius europaeus, T. asiaticus) [34]. }\end{array}$ \\
\hline $\begin{array}{c}31 \\
(846)\end{array}$ & Baffin Land & $-5--6$ & $>500$ & $\begin{array}{l}\text { A flat, vast post-glacial plain, composed mainly of limestone and shales } \\
\text { overlain by glacial and fine-grained lacustrine and marine sediments. Clay } \\
\text { soils and peat deposits predominate in lake basins. High density segregated } \\
\text { ice. Continuous permafrost.Vegetation: Wet sedge-meadows (Carex spp. and } \\
\text { Eriophorum spp.); Low shrub heath with (Salix arctica, Cassiope tetragona, } \\
\text { Betula glandulosa, Vaccinium vitisideae, Ledum palustre) and other heath plants, } \\
\text { and numerous herbs, grasses, and mosses; Semivegetated granite-gneiss } \\
\text { terrain (Salix herbacea, Saxifraga tricuspidata, Luzula confusa, Silene acaulis), and } \\
\text { abundant lichens; and Polar semidesert limestone barrens (Salix lanata, } \\
\text { Saxifraga oppositifolia, Leucanthemum integrifolium) [36]. }\end{array}$ \\
\hline $\begin{array}{c}40 \\
(670)\end{array}$ & $\begin{array}{c}\text { Koryak } \\
\text { Highlands, near } \\
\text { Palmatkina River }\end{array}$ & $-1--3$ & $50-150$ & $\begin{array}{l}\text { Glacio-fluvial valley, composed of alluvium and proluvium of "dry deltas", } \\
\text { which are pebbles with inclusions of gravel, sand, and boulders. Mainly } \\
\text { continuous permafrost. Ref. [33] Vegetation: southern hypoarctic tundra } \\
\text { (Betula exilis, Salix pulchra, S. glauca, S. krylovii, S. alaxensis, S. boganidensis, } \\
\text { S. richardsonii, Alnus fruticosa, Eriophorum vaginatum, Carex lugens) [34]. }\end{array}$ \\
\hline
\end{tabular}

Remote Sensing Data. We used the following remote sensing data:

- Archival Corona images with a resolution of 3-12 m/pix, June-August 1965-1976;

- $\quad$ New (June-August 2008-2014) images from satellites IKONOS, QuickBird, Worldview 2, Geoeye-1, Pleiades, SPOT-5, SPOT-6 with high resolution 0.5-2.5 m/pix, obtained both from open sources (Google earth, Yandex maps, Bing) and specially purchased (ScanEx R\&D Center). The description of space imagery is in Table 3. 
Table 3. Parameters of the remote sensing data.

\begin{tabular}{|c|c|c|c|c|c|c|c|}
\hline \multirow[b]{2}{*}{ Key Site } & \multicolumn{3}{|c|}{ Date 2} & \multicolumn{3}{|c|}{ Date 1} & \multirow{2}{*}{$\begin{array}{c}\text { Time } \\
\text { between } \\
\text { Surveys }\end{array}$} \\
\hline & Source of Imagery & $\begin{array}{l}\text { Survey } \\
\text { Date }\end{array}$ & $\begin{array}{l}\text { Resolution, } \\
\text { m/pix }\end{array}$ & $\begin{array}{l}\text { Source of } \\
\text { Imagery }\end{array}$ & Survey Date & $\begin{array}{l}\text { Resolution, } \\
\text { m/pix }\end{array}$ & \\
\hline \multicolumn{8}{|c|}{ Lacustrine thermokarst plains } \\
\hline AS10 & SPOT 5 & 17.07.2011 & 2.5 & Corona & 13.07.1964 & 2.7 & 47 \\
\hline AS14 & WorldView2 & 09.07.2014 & 0.5 & Corona & 19.08.1976 & 1.2 & 38 \\
\hline AS16 & QuickBird & 23.06.2011 & 0.64 & Corona & 21.07.1965 & 2.7 & 46 \\
\hline AS19 & SPOT 5 & 11.08 .2008 & 2.5 & Corona & 22.07.1965 & 2.7 & 43 \\
\hline AS21 & SPOT 5 & 10.08 .2008 & 2.5 & Corona & 14.08.1966 & 2.7 & 42 \\
\hline AS23 & QuickBird & 05.07.2011 & 0.64 & Corona & $\begin{array}{l}01.08 .1976 \\
18.07 .1976\end{array}$ & 1.2 & 35 \\
\hline AS3 & SPOT 5 & 14.09 .2011 & 2.5 & Corona & 22.07.1976 & 1.2 & 35 \\
\hline AS31 & Worldview2 & 24.06 .2011 & 0.5 & Corona & 21.08.1968 & 1.8 & 43 \\
\hline \multicolumn{8}{|c|}{ Thermokarst plains with fluvial erosion } \\
\hline 19 & WorldView2 & 28.07 .2013 & 0.5 & Corona & 14.08.1967 & 1.2 & 46 \\
\hline 20 & WorldView2 & 24.08 .2018 & 0.5 & Corona & 26.07.1972 & 1.2 & 46 \\
\hline 21 & WorldView2 & 10.07.2013 & 0.5 & Corona & 21.07.1965 & 4 & 48 \\
\hline 22 & Sentinel & 11.08 .2018 & 10 & Corona & 21.07.1965 & 3.4 & 53 \\
\hline 24 & SPOT 7 & 15.09 .2015 & 1.5 & Corona & 31.08 .1978 & 3 & 37 \\
\hline 25 & SPOT 6 & 03.08.2019 & 1.5 & Corona & 21.08.1968 & 2.1 & 51 \\
\hline 30 & SPOT 7 & 17.09.2017 & 1.5 & Corona & 07.07.1961 & 2 & 56 \\
\hline 31 & WorldView2 & 01.07.2017 & 0.5 & Corona & 04.07.1979 & 10 & 38 \\
\hline 40 & SPOT 7 & 07.08.2015 & 1.5 & Corona & 29.07.1969 & 2.2 & 46 \\
\hline
\end{tabular}

Research technique. The research is based on the mathematical morphology of landscapes, particularly modeling the morphological pattern development using the random process theory [37,38]. The modeling gave us informative, quantitative parameters of morphological patterns, and then we analyzed their temporal changes. The general technique is shown in Figure 5.

Key site selection. We selected the key sites by analyzing space imagery, published sources, and maps. The main requirements involved genetic, landscape, and morphological homogeneity, which were achieved by analyzing images and additional sources of information. Thus, territories with lakes of a different origin, usually expressed in their morphology, such as alluvial plains and ice-wedge polygonal plains, were excluded from the sites. The description of the key sites is presented in Tables 1 and 2.

We selected remote sensing data for the key sites of the lacustrine thermokarst plains and the thermokarst plains with fluvial erosion results based on the following requirements:

- $\quad$ Ensuring two shooting dates for each site;

- Maximizing the time between two shooting dates for each site;

- The maximum spatial resolution of space imagery.

Thus, we formed the set of space images for our research. The main parameters of the remote sensing data are presented in Table 3.

The selection of the parameters for the morphological patterns of the lacustrine thermokarst plains is based on the developed mathematical model [37,38]. 


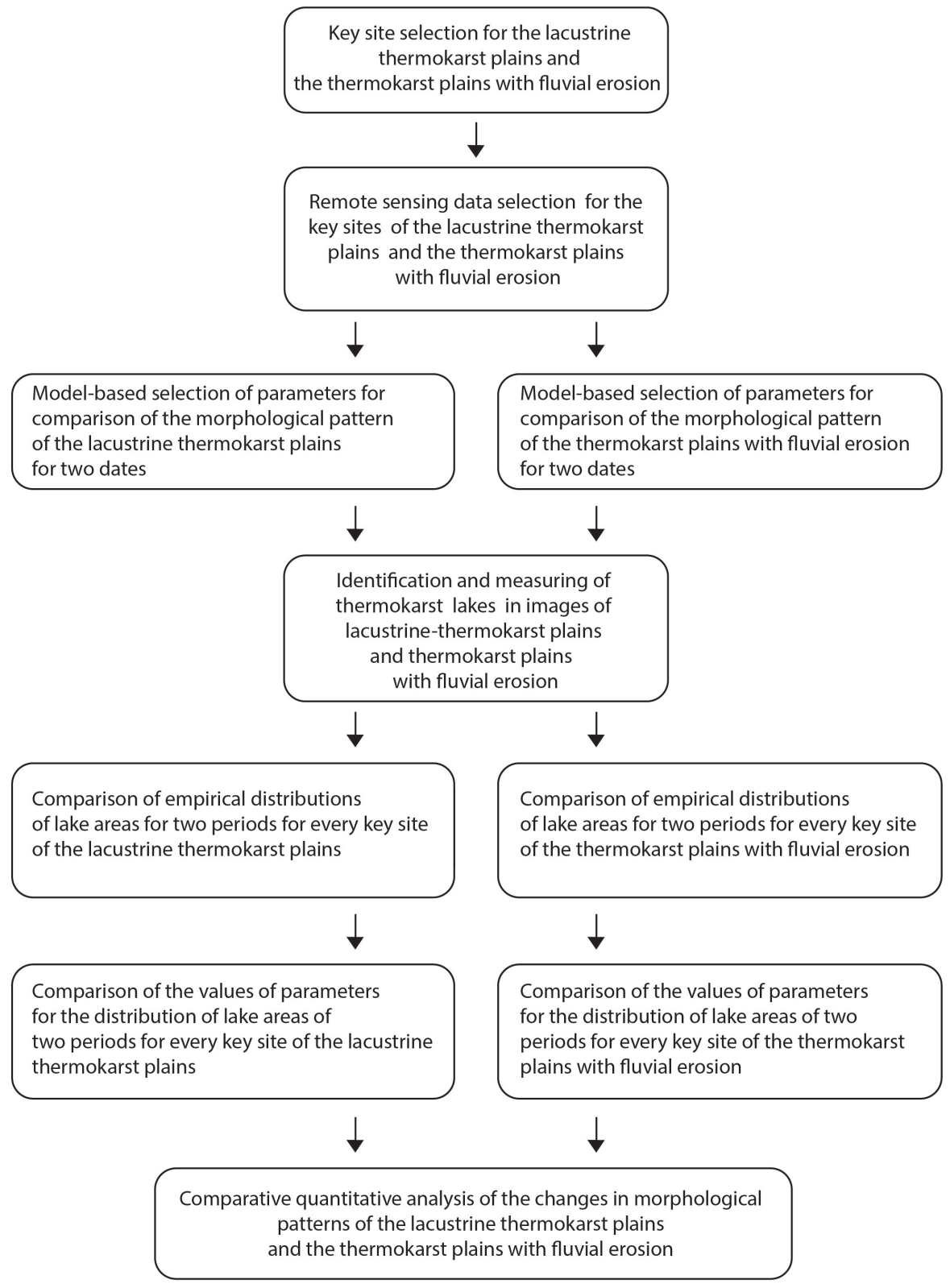

Figure 5. Block diagram of the research methodology for assessing changes in the morphological pattern of landscapes of lacustrine thermokarst plains and thermokarst plains with fluvial erosion.

The problem is that there are too many characteristics within the morphological pattern of the studied landscapes (lacustrine thermokarst plains in particular). However, they are in mutual dependence due to the formation laws of the morphological pattern. Therefore, we can detect a certain limited number of quantitative characteristics of the morphological pattern (the parameters), on which any other quantitative characteristics depend. Thus, such parameters reflect all quantitative changes in the morphological pattern. The mathematical models of the morphological patterns allow us to choose such parameters [37,38].

The morphological pattern model for homogeneous lacustrine thermokarst plains under the assumption of the approximately simultaneous appearance of primary thermokarst depressions ("synchronous start") is based on the following basic assumptions [38]: 
- $\quad$ The emergence of the initial depressions took a short time; it was a random process and developed independently within nonintersecting sites. The emergence probability of depressions at a test site depends only on its area.

- The growth of individual lakes due to the thermoabrasion impact (a low intensity of thermal abrasion is also possible, while the process approaches "purely thermokarst") occurs independently in each lake. It was directly proportional to the heat reserves in the lake and inversely proportional to the area of the side surface of the water body.

Our previous research empirically proved this model of lacustrine thermokarst plain morphological pattern development. However, we examined three more variants of the models, differing in asynchronous start and quasiuniform growth in the size of lakes (for example, Ref. [38]).

The mathematical analysis of the model gives us the following main laws of development for the analyzed morphological pattern:

- The distribution of the number of thermokarst depressions (centers) on a randomly chosen plot fits the Poisson law $[37,38]$, that is:

$$
P(k, s)=\frac{(\gamma s)^{k}}{k !} e^{-\gamma s},
$$

where $\gamma$ is the mean number of depressions per unit area, and $s$ is the area of the test site;

- Radius and area distributions of the thermokarst lakes after long development fit the lognormal distribution:

$$
f_{r}^{0}(x, t)=\frac{1}{\sqrt{2 \pi} \sigma_{0} x \sqrt{t}} e^{-\frac{\left(\ln x-a_{0} t\right)^{2}}{2 \sigma_{0}^{2} t}}
$$

where $a_{0}, \sigma_{0}$ are distribution parameters, $t$ is the time since the process began.

We can show that the obtained results are valid in the case of climatic changes in the cryolithozone [38]

Thus, the main changing parameters that characterize the state of the morphological pattern at each moment of its development are:

- A mean logarithm of the lake area:

$$
a(t)=a_{0} t
$$

- $\quad$ Variance in the lake area logarithm

$$
\sigma^{2}(t)=\sigma_{0}^{2} t
$$

The mean lake area and the lake's area percentage change in connection with these parameters.

For the full use of the information, in addition to the parameters selected for comparison, we made a comparison of the empirical distributions of lake areas on two dates at each key site of the lacustrine thermokarst plains.

The selection of parameters for comparing the morphological pattern of the thermokarst plains with fluvial erosion is based on the developed mathematical model of the morphological pattern of the thermokarst plains with fluvial erosion $[37,38]$. The formulation of the problem is the same as given above for the lacustrine thermokarst plains.

Our previous analysis $[39,40]$ showed that the empirical data are most consistent with the morphological pattern model for the thermokarst plains with fluvial erosion, corresponding to the asynchronous start. This can be explained by the ongoing formation of new thermokarst lakes within the emerging khasyreis. The model of the morphological pattern of the thermokarst plains with fluvial erosion under the assumption of the asynchronous start is based on the following basic assumptions:

- $\quad$ Emergences of initial thermokarst depressions (foci) are independent random events during nonintersecting periods and at nonintersecting sites; the emergence probability depends only on the period and the site values (For small sites, the probability of 
occurrence of more than one depression is infinitely small, to a higher order than the probability of the occurrence of one depression).

- The change in a thermokarst depression radius is a random variable; it does not depend on other lakes. Its growth rate under random factors is directly proportional to heat losses through the side (water-covered) surface of the lake depression.

- While growing, a lake can turn into a khasyrei after draining by a stream; the probability of this does not depend on the development of other lakes. If it happens, the depression stops growing.

- The origins of new sources of fluvial erosion within disjointed sites are independent random events; the probability of a source of a fluvial stream within a given site depends only on its area and is much higher than the probability of having more than one source (For small sites, the probability of occurrence of more than one source is infinitely small, to a higher order than the probability of the occurrence of one source).

- The initial thermokarst depressions cannot appear within already existing thermokarst lakes.

The mathematical analysis of the model (see [37]) gives us the following main laws for developing the morphological pattern under consideration:

- The radii distribution for the freely growing thermokarst lakes after time $\mathrm{t}$ since the occurrence of a particular lake fits the lognormal distribution.

$$
f_{0}(x, t)=\frac{1}{\sqrt{2 \pi} \sigma x \sqrt{t}} e^{-\frac{(\ln x-a t)^{2}}{2 \sigma^{2} t}},
$$

where $a, \sigma$ are distribution parameters;

- A distance distribution from the center of the growing focus to the nearest source of fluvial erosion, stopping the growth of the lake by turning it into khasyrei, fits the Rayleigh distribution:

$$
F(x)=1-e^{-\pi \gamma x^{2}},
$$

where $\gamma$ is the mean density of spatial arrangement of the sources;

- The number of initial thermokarst depressions that occurred at the start of the thermokarst process within a test site fits the Poisson law:

$$
P(k, t, s)=\frac{(\mu t s)^{k}}{k !} e^{-\mu t s},
$$

where $\mu$ is the mean number of depressions per unit area, $s$ is the area of the test site, and $t$ is the time since the process started.

This model was examined along with three other variants of the morphological pattern development model for the thermokarst plains with fluvial erosion (synchronous start, quasiuniform growth of lakes), and was confirmed as the most common [41] within the cryolithozone.

This model's analysis reveals the dynamic balance between the origin of new lakes and their transformation into khasyreis, which appear after a long period of development within a wide range of natural conditions [38,41,42]. This state demonstrates, in particular, the following established regularities:

- The lake area distribution (density distribution) for the area of the initial depression $\varepsilon$ (the integral exponential distribution) is:

$$
f_{s l}(x, \infty)=-\frac{2}{x E i(-\gamma \varepsilon)} e^{-\gamma x}, x \geq \varepsilon,
$$

- $\quad$ The mean lake area is

$$
\overline{s_{l}}=-\frac{1}{\gamma E i(-\gamma \varepsilon)} e^{-\gamma \varepsilon}
$$

- $\quad$ The mean thermokarst lake location density is 


$$
\tau_{l}=-\frac{\mu}{2 a} E i(-\varepsilon \gamma)\left[1-P^{*}\right]
$$

- The percentage of the lake area fits the expression:

$$
\ln \left[1-P^{*}\right]=-\frac{\mu}{2 a \gamma} e^{-\varepsilon \gamma}\left[1-P^{*}\right],
$$

where $a$ is the growth rate of size logarithm, $\mathrm{P}^{*}$ - is percentage of the lake area, and $E i(x)=\int_{-\infty}^{x} \frac{e^{u}}{u} d u, x<0$ is the exponential integral.

Thus, the main formal changing parameters describing the state of the developing morphological pattern include:

- The mean steam-source location density $\gamma$;

- The ratio of the new thermokarst foci generation density to the growth rate of the logarithm of the size $\frac{\mu}{a}$;

- $\quad$ The area of a primary thermokarst lake (pond) $\varepsilon$.

Instead, we can use another set of formal parameters. It is easy to show that they correspond one-to-one, and thus they also describe the existing changes:

- Mean area of thermokarst lakes;

- Mean thermokarst lake location density;

The size of primary thermokarst foci (this last parameter was not used due to its little changing).

For the full use of the information, in addition to the parameters selected for comparison, we made a comparison of the empirical distributions of lake areas on two dates at each key site of the thermokarst plains with fluvial erosion.

Identification and measuring of thermokarst lakes in images of lacustrine-thermokarst plains and thermokarst plains with fluvial erosion. We used automatic ARCGIS modules and manual data interpretation for thermokarst lake mapping, including special analysis to avoid interpretation errors. The research involves most lakes, including secondary lakes in the khasyreis. Only a few lakes were excluded from consideration, particularly small residual water bodies with indefinite boundaries in incompletely drained lake depressions. Additional detailed data on the site location and the images used for each study period, which show all the lakes under statistical processing, are provided in the resource https: / / disk.yandex.ru/d/fwGqmLWzXpb8-g (acessed on 7 December 2021). The area of the lakes was determined using the corresponding ARCGIS module. The error estimate for the lake area is an average of $2.9 \%$ for the first survey period (aerial survey) and $1.9 \%$ for the second survey period (high-resolution space imagery).

The comparison of empirical distributions of lake areas on two dates at every key site of the lacustrine thermokarst plains was based on the Smirnov Criterion (two-sample KolmogorovSmirnov test in STATISTICA). The hypothesis of no change was rejected at a significance level of 0.95 with a $p$-value less than 0.05 . The same procedure was carried out for the key sites of the thermokarst plains with fluvial erosion.

The comparison of the values of parameters for the distribution of lake areas of two dates for every key site of the lacustrine thermokarst plains was based on the previously proven $\log$ normality of the lake area distribution $[37,38]$. This allowed us to use the Fisher criterion to compare the logarithm variances of the lake areas and Student's criterion to compare the average logarithms of the lake areas.

A comparison of the values of parameters for the distribution of lake areas on two dates at every key site of the thermokarst plains with fluvial erosion was carried out by estimating the difference between the selected parameters - the average lake area and the average density of lakes-for the first and second dates, respectively. Since the averages were the sum of a large number of random variables, according to the central limit theorem, their distribution was close to normal; this allowed us to use Student's $t$-test to assess the significance of the differences. 
A comparative quantitative analysis of the changes in the morphological patterns of the lacustrine thermokarst plains and the thermokarst plains with fluvial erosion was conducted by comparing the proportion of key sites within each landscape that have changed. The changes identified by comparing the distributions of the areas of thermokarst lakes for two dates were considered separately from those identified by comparing the parameters.

\section{Results}

Our research provides results concerning changes in the morphological patterns of the lacustrine thermokarst plains, including:

- A comparison of the lake area distributions on two dates using the Smirnov criterion (Table 4);

- A comparison of the lake area distribution parameters on two dates (Table 5).

Table 4. Comparison of lake area distributions of lacustrine thermokarst plains for two dates using the Smirnov criterion *.

\begin{tabular}{cccccc}
\hline Key Site & $\begin{array}{c}\text { Sample } \\
\text { Volume } \\
\text { (Date 1) }\end{array}$ & $\begin{array}{c}\text { Sample } \\
\text { Volume } \\
\text { (Date 2) }\end{array}$ & $\begin{array}{c}\text { Max Neg } \\
\text { Differnc }\end{array}$ & $\begin{array}{c}\text { Max Pos } \\
\text { Differnc }\end{array}$ & $p$-Value \\
\hline AS3 & 180 & 176 & $-\mathbf{0 . 0 1 6 4 1 4}$ & $\mathbf{0 . 1 5 1 6 4 1}$ & $p<\mathbf{0 . 0 5}$ \\
\hline AS10 & 167 & 167 & -0.017964 & 0.035928 & $p>0.10$ \\
\hline AS14 & 153 & 154 & -0.008021 & 0.048256 & $p>0.10$ \\
\hline AS16 & 584 & 576 & -0.031369 & 0.024353 & $p>0.10$ \\
\hline AS19 & 209 & 209 & -0.038278 & 0.014354 & $p>0.10$ \\
\hline AS21 & 351 & 345 & -0.017292 & 0.023981 & $p>0.10$ \\
\hline AS23 & 109 & 108 & -0.013931 & 0.047995 & $p>0.10$ \\
\hline AS31 & 207 & 210 & -0.026363 & 0.027743 & $p>0.10$ \\
\hline
\end{tabular}

${ }^{*}$ The Smirnov criterion should be $p<0.05$ for a significant difference between the two samples (in bold).

Table 5. Comparison of the parameters of lake area distributions of lacustrine thermokarst plains for two dates.

\begin{tabular}{ccccccccc}
\hline Key Site & $\begin{array}{c}\text { Mean Area } \\
\text { Logarithm } \\
\text { (Date 1) }\end{array}$ & $\begin{array}{c}\text { Mean Area } \\
\text { Logarithm } \\
\text { (Date 2) }\end{array}$ & $\begin{array}{c}\text { Student's } \\
\text { Criterion }\end{array}$ & $\begin{array}{c}\text { Critical } \\
\text { Value at } \\
\text { the Level } \\
\text { of } \mathbf{0 . 9 5}\end{array}$ & $\begin{array}{c}\text { Logarithm } \\
\text { Variance } \\
\text { (Date 1) }\end{array}$ & $\begin{array}{c}\text { Logarithm } \\
\text { Variance } \\
\text { (Date 2) }\end{array}$ & $\begin{array}{c}\text { Fisher's } \\
\text { Criterion }\end{array}$ & $\begin{array}{c}\text { Critical } \\
\text { Value at } \\
\text { the Level } \\
\text { of 0.95 }\end{array}$ \\
\hline AS 23 & 12.21 & 12.17 & 0.21 & 1.96 & 1.88 & 1.95 & 1.04 & 1.26 \\
\hline AS 21 & 10.83 & 10.82 & 0.10 & 1.96 & 1.53 & 1.61 & 1.05 & 1.1 \\
\hline AS 19 & 10.90 & 10.92 & 0.16 & 1.96 & 1.51 & 1.54 & 1.02 & 1.14 \\
\hline AS 14 & 11.63 & 11.55 & 0.53 & 1.96 & 1.64 & 1.81 & 1.10 \\
\hline AS 16 & 10.14 & 10.17 & 0.29 & 1.96 & 2.97 & 3.12 & 1.05 \\
\hline AS 10 & 11.94 & 11.92 & 0.13 & 1.96 & 2.04 & 2.07 & 1.02 \\
\hline AS 31 & 9.11 & 8.99 & 0.22 & 1.96 & 5.64 & 5.48 & 1.06 \\
\hline AS 3 & 9.64 & 9.42 & 1.05 & 1.96 & 3.50 & 4.30 & 1.18 \\
\hline
\end{tabular}

The Smirnov criterion, assessing the statistical differences between the two samples of the thermokarst lake areas for each key site from 1965 to 1976 and 2008 to 2014, revealed a statistically significant difference only for one site (AS3). Comparing the model parameters, such as the mean logarithms and variances of the logarithms of the thermokarst lake areas, shows changes in the values of the parameters. However, Fisher and Student's statistical tests do not reveal significant differences (at a significance level of 0.95) in the 
studied parameters for the two survey dates. We only found differences in the variance at the 0.95 significance level at the AS3 site. The AS3 site, where statistically significant differences were found both in the variance of the lake areas and in the distributions in general, is located on the Yamal Peninsula. Thus, a change in the morphological pattern of the lacustrine thermokarst plains was found in one key site out of eight, which is equal to $12 \%$.

We analyzed changes in the morphological pattern of the thermokarst plains with fluvial erosion using various key sites and two dates of observation:

- $\quad$ Date 1: 1964-1980;

- $\quad$ Date 2: 2011-2019.

The minimum period between two dates for a key site is 38 years, and the maximum period between two dates for a key site is 56 years. For all these key sites, we obtained the changes in the lake area distribution (Table 6), mean area (Table 7), and mean location density of the thermokarst lakes (Table 8).

Checking the statistical differences between the two samples of the thermokarst lake areas for each key site from 1964 to 1980 and 2011 to 2019 with the Smirnov criterion revealed a statistically significant difference between two key sites (20 and 24). Comparing the model parameters shows some change in the average area of the thermokarst lakes. However, Student's t-test proves that none of these changes are statistically significant. A comparison of the values of the average location density of thermokarst lakes also shows the absence of statistically significant changes. Thus, it can be stated that changes in the morphological pattern of the thermokarst plains with fluvial erosion were found in two out of nine key sites, which is equal to $22 \%$. Both key sites with identified changes are located on the Yamal Peninsula.

Table 6. Comparison of the lake area distributions of the thermokarst plains with fluvial erosion for two dates using the Smirnov criterion *.

\begin{tabular}{cccccc}
\hline Key Site & $\begin{array}{c}\text { Sample } \\
\text { Volume } \\
\text { (Date 1) }\end{array}$ & $\begin{array}{c}\text { Sample } \\
\text { Volume } \\
\text { (Date 2) }\end{array}$ & $\begin{array}{c}\text { Max Neg } \\
\text { Diff }\end{array}$ & $\begin{array}{c}\text { Max Pos } \\
\text { Diff }\end{array}$ & $p$-Value \\
\hline 19 & 205 & 205 & -0.078 & 0.014 & $>0.10$ \\
\hline 20 & 359 & 372 & $-\mathbf{0 . 1 5 0}$ & $\mathbf{0 . 0 0 2}$ & $<\mathbf{0 . 0 0 1}$ \\
\hline 21 & 430 & 433 & -0.007 & 0.04 & $>0.10$ \\
\hline 22 & 291 & 298 & -0.004 & 0.056 & $>0.10$ \\
\hline 24 & 381 & 362 & $-\mathbf{0 . 1 0 0}$ & $\mathbf{0 . 0 1 1}$ & $<\mathbf{0 . 0 5}$ \\
\hline 25 & 314 & 309 & -0.073 & 0.009 & $>0.10$ \\
\hline 22 & 291 & 298 & -0.004 & 0.056 & $>0.10$ \\
\hline 30 & 524 & 522 & -0.043 & 0.007 & $>0.10$ \\
\hline 31 & 100 & 95 & -0.040 & 0.037 & $>0.10$ \\
\hline 40 & 553 & 549 & -0.031 & 0.043 & $>0.10$ \\
\hline
\end{tabular}

* The Smirnov criterion should be $p<0.05$ for a significant difference between the two samples (in bold). 
Table 7. Parameters of changes of morphological patterns for key sites of thermokarst plains with fluvial erosion: mean lake area.

\begin{tabular}{ccccc}
\hline Key Site & $\begin{array}{c}\text { Mean Lake } \\
\text { Area }\left(\mathbf{k m}^{\mathbf{2}}\right) \\
(\text { Date } \mathbf{~})\end{array}$ & $\begin{array}{c}\text { Mean Lake } \\
\text { Area }\left(\mathbf{k m}^{\mathbf{2}}\right) \\
(\text { Date } \mathbf{)}\end{array}$ & $\begin{array}{c}\text { Student's } \\
\text { Criterion }\end{array}$ & $\begin{array}{c}\text { Critical Value at } \\
\text { the Level of 0.95 }\end{array}$ \\
\hline 19 & 0.049 & 0.043 & 0.53 & 1.96 \\
\hline 20 & 0.126 & 0.134 & 0.11 & 1.96 \\
\hline 21 & 0.225 & 0.233 & 0.20 & 1.96 \\
\hline 22 & 0.314 & 0.333 & 0.23 & 1.96 \\
\hline 24 & 0.073 & 0.072 & 0.03 & 1.96 \\
\hline 25 & 0.083 & 0.075 & 0.72 & 1.96 \\
\hline 30 & 0.058 & 0.054 & 0.61 & 1.96 \\
\hline 31 & 0.908 & 0.761 & 0.83 & 1.96 \\
\hline 40 & 0.032 & 0.028 & 1.04 & \\
\hline
\end{tabular}

Table 8. Parameters of changes of morphological patterns for key sites of thermokarst plains with fluvial erosion: mean lake location density.

\begin{tabular}{lcccc}
\hline & $\begin{array}{c}\text { Mean Lake Location Density } \\
\left(\mathbf{k m}^{-2}\right) \text { (Date 1) }\end{array}$ & $\begin{array}{c}\text { Mean Lake Location } \\
\text { Density (km } \mathbf{- 2}) \\
\text { (Date } \mathbf{)}\end{array}$ & $\begin{array}{c}\text { Student's } \\
\text { Criterion }\end{array}$ & $\begin{array}{c}\text { Critical Value at } \\
\text { the Level of 0.95 }\end{array}$ \\
\hline 19 & 0.99 & 0.99 & 0 & 1.96 \\
\hline 20 & 0.80 & 0.83 & 0.50 & 1.96 \\
\hline 21 & 0.37 & 0.37 & 0 & 1.96 \\
\hline 22 & 0.10 & 0.10 & 0 & 1.96 \\
\hline 24 & 2.47 & 2.35 & 0.68 & 1.96 \\
\hline 25 & 1.55 & 1.53 & 0.16 & 1.96 \\
\hline 30 & 1.19 & 1.18 & 0.14 & 1.96 \\
\hline 31 & 0.12 & 0.11 & 0.61 & 1.96 \\
\hline 40 & 0.83 & 0.82 & 0.20 & 1.96 \\
\hline
\end{tabular}

\section{Discussion}

The analysis of the obtained results shows that the morphological patterns of the lacustrine thermokarst plains and the thermokarst plains with fluvial erosion do not demonstrate significant signs of their evolution despite essential climatic changes. This is evidenced by the practical absence of statistically significant changes in the studied parameters, selected based on mathematical models of the corresponding landscapes. Thus, they cover all the free parameters of the models, and accordingly, reflect changes in all of the quantitative characteristics of the morphological patterns. In this case, we are talking about a time interval of 40-60 years.

At the same time, a more detailed analysis shows a trend towards some changes. First of all, this is revealed by statistically significant changes in the thermokarst lake area distributions fixed by the Smirnov criterion in some key sites for both the lacustrine thermokarst plains and thermokarst plains with fluvial erosion (Figure 6). 


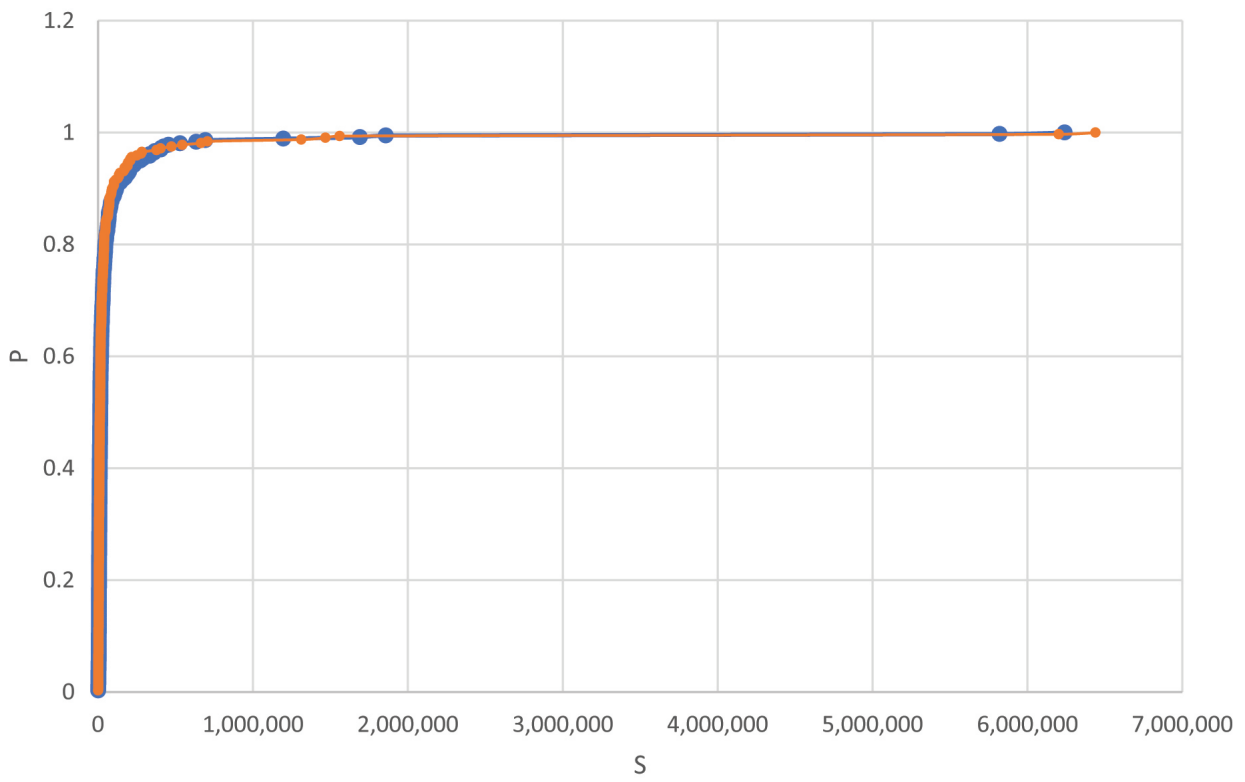

Figure 6. Comparison between empirical distributions for Date 1 and Date 2 (key site 20 as an example). The $x$-axis indicates the size of the lakes in meters; the $y$-axis indicates the probability.

The results of a more detailed analysis of the selected parameters also demonstrate the presence of this trend. However, the Fisher's and Student's statistical tests did not reveal significant differences (at a significance level of 0.95 ) in the studied parameters for the two survey dates, except the AS3 site. Nevertheless, the comparison of the model parameters - the average logarithms of the thermokarst lake areas on two dates at each key site and, similarly, the variances of the logarithms of the thermokarst lake areas-shows a slight decrease in the average logarithm in all key sites except one and some increase in the variance in all key sites except one. Thus, it is interesting that the observed differences for the first and second dates for different sites almost always have the same negative sign, which can hardly be accidental.

The analysis of the location density of the thermokarst lakes within the thermokarst plains also shows that the parameter decreased in five key sites and only increased in one. The change in the average lake area has more diverse trends, with a predominant decrease.

A comparison of the data obtained with the results of other researchers shows that many studies have concluded that the average areas of thermokarst lakes have changed. Thus, an overall increase in the average area of thermokarst lakes has been observed in various areas, particularly in Eastern Siberia [43,44]. Some studies have noted a reduction in thermokarst lake areas in Western Siberia and Alaska, which is more pronounced in low latitudes $[45,46]$.

We think that the discrepancy between the conclusions can be explained by the fact that the authors of these studies investigated all the lakes in their key areas without considering their morphological and physiographic homogeneity. Accordingly, lakes of differing geneses, in different physical and geographical environments, and possibly with different tendencies of change, were analyzed. In addition, the mentioned studies did not separate the landscapes of lacustrine thermokarst plains and thermokarst plains with fluvial erosion. Meanwhile, the set of processes of the morphological patterns of these landscapes is significantly different, as we discussed above.

A comparison of the obtained data on the lacustrine thermokarst plains and thermokarst plains with fluvial erosion shows that for the thermokarst plains with fluvial erosion the degree of change in the morphological pattern is higher than that of lacustrine thermokarst plains-22\% versus $12 \%$. We can explain the different changeability of the morphological patterns of the analyzed landscapes because fluvial erosion reacts to climatic changes first and leads to a change in the thermokarst lake area distributions of the thermokarst 
plains with fluvial erosion by the intensification of their drainage and transformation into khasyreis. The change in the thermokarst process itself is perhaps more inertial, and has a more gradual reaction to ongoing climatic changes.

The geographical analysis shows that all sites with statistically significant changes are located in the Yamal Peninsula.

\section{Conclusions}

According to our quantitative analysis:

- $\quad$ The morphological patterns of lacustrine thermokarst plains and thermokarst plains with fluvial erosion do not demonstrate significant evolution despite climatic changes during the observation period;

- Changes in the morphological pattern of thermokarst plains with fluvial erosion are somewhat greater than those of lacustrine thermokarst plains and, accordingly, the risk for engineering structures is also higher;

- The different variability of the morphological patterns of the analyzed landscapes can be explained by fluvial erosion, which first reacts to climatic changes, leading to a change in the area distributions of thermokarst lakes in thermokarst plains with fluvial erosion and the acceleration of their drainage and transformation into khasyreis.

Author Contributions: Conceptualization A.V.; methodology A.V.; validation, V.K.; formal analysis V.K.; investigation, T.O.; resources, T.O.; data curation, M.A.; writing-original draft preparation, A.V., V.K., and T.O.; writing-review and editing, O.T.; visualization, T.O. and M.A.; supervision, A.V.; project administration, T.O.; funding acquisition, A.V. All authors have read and agreed to the published version of the manuscript.

Funding: This research was funded by the Russian Science Foundation project 18-17-00226.

Data Availability Statement: Additional detailed data on the site location and the images used for each study period, which show all the lakes under statistical processing, are given on the resource https:/ / disk.yandex.ru/d/fwGqmLWzXpb8-g (accessed on 4 February 2022).

Conflicts of Interest: The authors declare no conflict of interest.

\section{References}

1. Kotlyakov, V.M.; Velichko, A.A.; Glazovsky, A.F.; Tumskaya, V.E. The past and present-day arctic cryosphere. Her. Russ. Acad. Sci. 2015, 85, 251-259. [CrossRef]

2. Sazonova, T.S.; Romanovsky, V.E.; Walsh, J.E.; Sergueev, D.O. Permafrost dynamics in the 20th and 21st centuries along the East Siberian transect. J. Geophys. Res. 2004, 109, D01108. [CrossRef]

3. Jafarov, E.E.; Marchenko, S.S.; Romanovsky, V.E. Numerical modeling of permafrost dynamics in Alaska using a high spatial resolution dataset. Cryosphere 2012, 6, 613-624. [CrossRef]

4. Oberman, N.G.; Mazhitova, G.G. Permafrost dynamics in the north-east of European Russia at the end of the 20th century. Nor. Geogr. Tidsskr. 2010, 55, 241-244. [CrossRef]

5. Sergeev, D.O.; Chesnokova, I.V.; Bezdelova, A.P.; Dernova, E.O. Results of permafrost geocryological monitoring for the period 1986-2019: State and dynamics of mountain permafrost. Stability of natural and technical systems in permafrost. In Proceedings of the All-Russian Conference with International Participation Dedicated to the 60th Anniversary of the Formation of the Institute of Permafrost, Yakutsk, Russia, 28-30 September 2020; pp. 164-168. (In Russian).

6. Farquharson, L.M.; Romanovsky, V.E.; Cable, W.L.; Walker, D.A.; Kokelj, S.V.; Nicolsky, D. Climate change drives widespread and rapid thermokarst development in very cold permafrost in the Canadian High Arctic. Geophys. Res. Lett. 2019, 46, 6681-6689. [CrossRef]

7. Morgenstern, A.; Overduin, P.P.; Günther, F.; Stettner, S.; Ramage, J.; Schirrmeister, L.; Grigoriev, M.N.; Grosse, G. Thermoerosional valleys in Siberian ice-rich permafrost. Permafr. Periglac Process 2021, 32, 59-75. [CrossRef]

8. Nicolsky, D.J.; Romanovsky, V.E.; Panda, S.K.; Marchenko, S.S.; Muskett, R.R. Applicability of the ecosystem type approach to model permafrost dynamics across the Alaska North Slope. J. Geophys. Res. Earth Surf. 2017, 122, 50-75. [CrossRef]

9. Nitze, I.; Grosse, G.; Jones, B.M.; Romanovsky, V.E.; Boike, J. Remote sensing quantifies widespread abundance of permafrost region disturbances across the Arctic and Subarctic. Nat. Commun. 2018, 9, 5423. [CrossRef]

10. Gibson, C.M.; Chasmer, L.E.; Thompson, D.K.; Quinton, W.L.; Flannigan, M.D.; Olefeldt, D. Wildfire as a major driver of recent permafrost thaw in boreal peatlands. Nat. Commun. 2018, 9, 3041. [CrossRef] 
11. Farquharson, L.; Mann, D.H.; Grosse, G.; Jones, B.; Romanovsky, V. Spatial distribution of thermokarst terrain in Arctic Alaska. Geomorphology 2016, 273, 116-133. [CrossRef]

12. Grosse, G.; Romanovsky, V.; Walter, K.; Morgenstern, A.; Lantuit, H.; Zimov, S. Distribution of Thermokarst Lakes and Ponds at Three Yedoma Sites in Siberia. In Proceedings of the Ninth International Conference on Permafrost, Fairbanks, AL, USA, 28 June-3 July 2008; pp. 551-556.

13. Anderson, L.; Edwards, M.; Shapley, M.D.; Finney, B.P.; Langdon, C. Holocene thermokarst lake dynamics in northern Interior Alaska: The interplay of climate, fire, and subsurface hydrology. North Pac. Environ. Paleoclimate Late Pleistocene Present $2019,7,53$. [CrossRef]

14. Edwards, M.; Grosse, G.; Jones, B.M.; McDowell, P. The evolution of a thermokarst-lake landscape: Late Quaternary permafrost degradation and stabilization in interior Alaska. Sediment. Geol. 2016, 340, 3-14. [CrossRef]

15. Swanson, D.K. Thermokarst and precipitation drive changes in the area of lakes and ponds in the National Parks of northwestern Alaska, 1984-2018. Arct. Antarct. Alp. Res. 2019, 51, 265-279. [CrossRef]

16. Veremeeva, A.; Nitze, I.; Günther, F.; Grosse, G.; Rivkina, E. Geomorphological and Climatic Drivers of Thermokarst Lake Area Increase Trend (1999-2018) in the Kolyma Lowland Yedoma Region, North-Eastern Siberia. Remote Sens. 2021, 13, 178. [CrossRef]

17. Dvornikov, Y.; Leibman, M.; Heim, B.; Bartsch, A.; Herzschuh, U.; Skorospekhova, T.; Fedorova, I.; Khomutov, A.; Widhalm, B.; Gubarkov, A.; et al. Terrestrial CDOM in lakes of Yamal peninsula: Connection to lake and lake catchment properties. Remote Sens. 2018, 10, 167. [CrossRef]

18. Lantz, T.C.; Turner, K.W. Changes in lake area in response to thermokarst processes and climate in Old Crow Flats, Yukon. J. Geophys. Res. Biogeosciences 2015, 120, 513-524. [CrossRef]

19. Jones, B.M.; Grosse, G.D.A.C.; Arp, C.D.; Jones, M.C.; Anthony, K.W.; Romanovsky, V.E. Modern thermokarst lake dynamics in the continuous permafrost zone, northern Seward Peninsula, Alaska. J. Geophys. Res. Biogeosciences 2011, 116, 1-13. [CrossRef]

20. Belshe, E.F.; Schuur, E.; Grosse, G. Quantification of upland thermokarst features with high resolution remote sensing. Environ. Res. Lett. 2013, 8, 035016. [CrossRef]

21. Chen, M.; Rowland, J.; Wilson, C.; Altmann, G.; Brumby, S. Temporal and spatial pattern of thermokarst lake area changes at Yukon Flats, Alaska. Hydrol. Processes 2014, 28, 837-852. [CrossRef]

22. Jones, B.M.; Grosse, G.; Farquharson, L.M.; Roy-Léveillée, P.; Veremeeva, A.; Kanevskiy, M.Z.; Gaglioti, B.V.; Breen, A.L.; Parsekian, A.D.; Ulrich, M.; et al. Lake and drained lake basin systems in lowland permafrost regions. Nat. Rev. Earth Environ. 2022, 3, 85-98. [CrossRef]

23. Polishchuk, V.Y.; Polishchuk, Y.M. Geoimitation Modeling of Thermokarst Lake Fields in Permafrost Zones; Yugra State University Press: Khánty-Mansíysk, Russia, 2013; (In Russian with English Summary).

24. Nitze, I.; Grosse, G.; Jones, B.M.; Arp, C.D.; Ulrich, M.; Fedorov, A.; Veremeeva, A. Landsat-Based Trend Analysis of Lake Dynamics across Northern Permafrost Regions. Remote Sens. 2017, 9, 640. [CrossRef]

25. Muster, S.; Riley, W.J.; Roth, K.; Langer, M.; Cresto Aleina, F.; Koven, C.D.; Lange, S.; Bartsch, A.; Grosse, G.; Wilson, C.J.; et al Size distributions of Arctic waterbodies reveal consistent relations in their statistical moments in space and time. Front. Earth Sci. 2019, 7, 5. [CrossRef]

26. Morgenstern, A.; Grosse, G.; Günther, F.; Fedorova, I.; Schirrmeister, L. Spatial analyses of thermokarst lakes and basins in Yedoma landscapes of the Lena Delta. Cryosphere Discuss. 2011, 5, 849-867. [CrossRef]

27. Olefeldt, D.; Goswami, S.; Grosse, G.; Hayes, D.; Hugelius, G.; Kuhry, P.; McGuire, A.D.; Romanovsky, V.E.; Sannel, A.B.K.; Schuur, E.A.G.; et al. Arctic Circumpolar Distribution and Soil Carbon of Thermokarst Landscapes 2015; ORNL DAAC: Oak Ridge, TN, USA, 2016. [CrossRef]

28. Pekel, J.-F.; Cottam, A.; Gorelick, N.; Belward, A.S. High-resolution mapping of global surface water and its long-term changes. Nature 2016, 540, 418-422. [CrossRef] [PubMed]

29. Theodoratos, N.; Seybold, H.; Kirchner, J.W. Scaling and similarity of a stream-power incision and linear diffusion landscape evolution model. Earth Surf. Dyn. 2018, 6, 779-808. [CrossRef]

30. Grau Galofre, A.; Jellinek, A.M. The geometry and complexity of spatial patterns of terrestrial channel networks: Distinctive fingerprints of erosional regimes. J. Geophys. Res. Earth Surf. 2017, 122, 1037-1059. [CrossRef]

31. Perron, J.; Kirchner, J.; Dietrich, W. Formation of evenly spaced ridges and valleys. Nature 2009, 460, 502-505. [CrossRef]

32. Geological Map of Russia. Available online: http://webmapget.vsegei.ru/index.html (accessed on 4 February 2022).

33. Ogureeva, G.N.; Leonova, N.B.; Buldakova, E.V.; Kadetov, N.G.; Arkhipova, M.V.; Miklyaeva, I.M.; Bocharnikov, M.V.; Dudov, S.V.; Ignatova, E.A.; Ignatov, M.S.; et al. The Biomes of Russia. Map. Scale 1:7,500,00/Москва 2018. Available online: https:/ / www.elibrary.ru/item.asp?id=36725020 (accessed on 4 February 2022).

34. Viereck, L.A.; Dyrness, C.T.; Batten, A.R.; Wenzlick, K.J. The Alaska Vegetation Classification; PNW-GTR-286; Department of Agriculture, Forest Service, Pacific Northwest Research Station: Portland, OR, USA, 1992; 278p.

35. Jacobs, J.D.; Hedley, A.N.; Maus, L.A.; Mode, W.N.; Simms, E.L. Climate and Vegetation of the Interior Lowlands of Southern Baffin Island: Long-Term Stability at the Low Arctic Limit. Arctic 1997, 50, 101-200. [CrossRef]

36. Victorov, A.S. The Main Problems of the Mathematical Morphology of the Landscape; Maik Nauka-Interperiodica Publishing: Moscow, Russia, 2006; p. 252. (In Russian) 
37. Victorov, A.S.; Orlov, T.V.; Kapralova, V.N.; Trapeznikova, O.N.; Arkhipova, M.V.; Berezin, P.V.; Zverev, A.V.; Sadkov, S.A.; Panchenko, E.G. Mathematical Morphology of Permafrost Landscapes; Publishing house of RUDN University: Moscow, Russia, 2016; p. 230, (In Russian with English Summary).

38. Victorov, A.S. Mathematical Morphology of Landscape; Tratek: Moscow, Russia, 1998; p. 180. (In Russian)

39. Alexey, V.; Maria, A.; Olga, T. Dynamic balance of the landscape morphological pattern of alluvial plains: The quantitative aspect. In Proceedings of the 20th International Multidisciplinary Scientific GeoConference SGEM 2020, Albena, Bulgaria, 16-25 August 2020; pp. 207-214. [CrossRef]

40. Victorov, A.S.; Orlov, T.V.; Trapeznikova, O.N.; Kapralova, V.N.; Arkhipova, M.V. Regularities of the distribution of lake areas on thermokarst plains with fluvial erosion. Dokl. Earth Sci. 2020, 491, 282-284. [CrossRef]

41. Victorov, A.S.; Orlov, T.V.; Arkhipova, M.V. Laws for size distribution of khasyreis. Dokl. Earth Sci. 2019, 488, 1253-1255. [CrossRef]

42. Polishchuk, Y.M.; Bryksina, N.A.; Kupriyanov, M.A. Comparative analysis of changes in the size of lakes in the permafrost zone of Western and Eastern Siberia based on satellite images. Geoinformatika 2016, 1, 64-67.

43. Sejourne, A.; Costard, F.; Fedorov, A.; Gargani, J.; Skorve, J.; Masse, M.; Mege, D. Evolution of the banks of thermokarst lakes in Central Yakutiya (Central Siberia) due to retrogressive thaw slump activity controlled by insolation. Geomorphology 2015, 241, 31-40. [CrossRef]

44. Riordan, B.; Verbyla, D.; McGuire, A.D. Shrinking ponds in subarctic Alaska based on 1950-2002 remotely sensed images. J. Geophys. Res. 2006, 111, G04002. [CrossRef]

45. Kravtsova, V.I.; Bystrova, A.G. Study of changes in the distribution of thermokarst lakes in Russia based on satellite images of different times. Kriosf. Zemli 2009, 15, 16-26.

46. Dneprovskaya, V.P.; Bryksina, N.A.; Polishchuk, Y.M. Study of thermokarst changes in the zone of discontinuous distribution of permafrost in Western Siberia on the basis of satellite images. Issled. Zemli Kosm. 2009, 3, 88-96. 